that in those days the catching of rinaway negroes, under the infamous fugitive slave law, was rife in the land, and detachments of the federal army, or vessels of the-U.S. Navy, could be readily secured to return a slave to his master. Henry Wilson's "Rise and Fall of the Slave Power," and the "Life of Anthony Burns," fully confirm these statements.

"The Tragedy at Minuewaukon" is the title of the con-" cluding article in "John Brown.among the Quakers and Other Sketches," a neat little volume. by Hon. Irving $B$. Richman, of Muscative (Des Moines, 1895), which may be found in most Iowa libraries. This is a clearly written and most interesting history of the massacre and the causes which led to it, including an account.of the captivity of Miss Abbie Gardner, the present Mrs. Sharp, who was so largely instrumeutal in securing the erection of the beatiful mounment at Lake Okoboji.

The Midland Monthy (Des Moines, Iowa), Vol. IV, contains two valuable illustrated articles on the Massacre and the Expedition. One of these was by Ex Gov. C. C. Carpenter, pp. 17-31; the other by Mrs. Abbie Garduer Sbarp, pp. 32-39.

\title{
AUTOGRAPHS OF JULIEN DUBUQUE.
}

There is not in all probability a scrap of the hand writing of this old miner and Indian trader within the limits of this State, notwithstanding he left his name so prominently identified with our early settlements. It has been believed by those who have thought upon the subject that the papers of the Choutean family of St. Louis would be found to contain many letters or other business papers in Dubuque's handwriting, and historical collectors have been looking forward to the proposed division of those documents among the northwestern states, in the belief that much valuable information would be brought to light. Letters by this "first white man who lived in what is now the State of Iowa," would be both interesting and valuable. Several weeks ägo the Editor of The Annals called upon Colonel Pierre 
Choutean at his office in St. Louis, for the purpose of learning what prospects we have of securing a share of these valuable papers. We learned with regret that it is not at all flattering. In fact, these documents are likely to be retained permanently in St. Louis. A project is now on foot in that city to celebrate the centennial of the Louisiana Purchase, not by an exposition, but by a meeting of representative people, in 1903, from all of the states into which that territory was divided. As one result of this meeting it is expected that a.western historical association will be organized with its headquarters in St. Louis. In that case, these Chouteau papers will not be distributed among the northwestern states, as was announced a year or so since, but will be arranged for permanent preservation and turned over to this proposed historical association, as a part of its archives. In the work of arranging the details of this great centennial the Hon. Fred W. Lehman, late of Des Moines, will take a prominent part, and certainly the West does not contain a man better informed or more competent for such an undertaking. But while the writer was in the office of Colonel Choutean he was shown a business paper in the French language, which bore in two places the signatures of "Aug. Chouteau"-one of the founders of the city of St. Louis, and the head of the greatest business organization of early times in the West-and "J. Dubuque." We believe this is the first time that any Iowa man now living has seen a scrap of Dubuque's handwriting. The chance that Iowa will obtain any paper written or signed by the old pioneer depends upon whether another is found. It is likely, however, that there are others-though the existence among the Choutean papers of letters by Dubuque is doubtful-and in case there are, one certainly will come to our Historical Department.

\section{ORIGIN AND SIGNIFICATION OF THE WORD "DES MOINES."}

In the present number of The AnNaLs the reader will find a very interesting article from the pen of Dr. Charles R. Keyes, in which be presents a highly plausible theory of the 
Copyright of Annals of Iowa is the property of State of Iowa, by \& through the State Historical Society of Iowa and its content may not be copied or emailed to multiple sites or posted to a listserv without the copyright holder's express written permission. However, users may print, download, or email articles for individual use. 